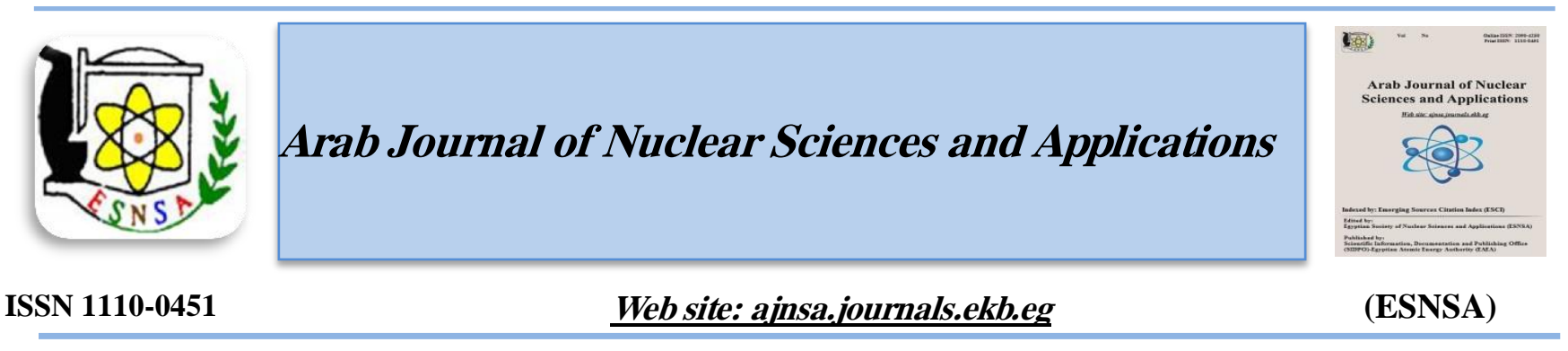

\title{
Allocating the Residues Cost of a Typical HTGR Directly Integrated with Steam Cycle Using Distributed Entropy Method
}

\author{
Seyyed Masoud Seyyedi ${ }^{\text {a,*, }}$, Masoud Khaleghi ${ }^{b}$, Mehdi Hashemi-Tilehnoee ${ }^{c}$ \\ ${ }^{a}$ Department of Mechanical Engineering, Aliabad Katoul Branch, Islamic Azad University, Aliabad Katoul, Iran \\ ${ }^{b}$ Department of Mechanical Engineering, Sirjan University of Technology, Kerman, Iran \\ ${ }^{c}$ Young Researchers and Elite Club, Aliabad Katoul Branch, Islamic Azad University, Aliabad Katoul, Iran
}

Received $19^{\text {th }}$ May 2018 Exergetic cost theory (ECT) method, is a conventional exergoeconomic analysis method. In energy Accepted $28^{\text {th }}$ Jul. 2018 systems, disposing of remaining flows of matter or energy is called residues. Distributed entropy (DE) method is an important method for allocating the residues cost. In this study, ECT method and the DE method are applied to a high-temperature gas-cooled reactor (HTGR) that is coupled with the steam cycle through the heat exchanger. Exergetic cost and exergoeconomic cost are obtained for each stream. Then residues cost distribution ratio is calculated using ECT and DE methods. The results have been compared with a model based on the disaggregation of physical exergy into its enthalpic and entropic terms which known as "H\&S" model. The results show that the DE method performed similar to the H\&S model, but the DE method is a rational criterion to allocate the cost of the residues. The unit product cost of HTGR turbine and steam turbine are calculated as 0.2526 cents/kWh and 1.1500 cents/kWh, respectively. The maximum product unit exergoeconomic cost value is 3.1420 cents/kWh that is corresponding to a steam cycle superheater.

Keywords: Exergoeconomic; Residues; Cost allocation; Exergetic cost theory; Distributed entropy; HTGR

\section{Introduction}

In energy systems, exergy can be defined as maximum work that can be obtained from a flow of matter or energy. By applying exergy analysis to the energy systems, the number of irreversibilities and the location of irreversibilities can be determined. The combination of exergy analysis with economic constraints is called exergoeconomic analysis. Exergoeconomic methods the grouped into two classes; the calculus methods and the algebraic methods $[1,2]$. Exergetic cost theory (ECT) method [3], average cost theory (ACT) method [4], specific exergy costing method (SPECO) [5], and modified productive structural analysis (MOPSA) [6,7] are the algebraic methods. On the other hand, thermoeconomical functional analysis (TFA) [8] and engineering functional analysis (EFA) [9] belong to calculus methods. In 1999, structural theory of thermoeconomics as a common mathematical language for exergoeconomics was proposed by Erlach et al. [10]. One of the not attended concepts of energy systems is the disposal of remaining flows of matter or energy that are called residues. Many researchers have investigated the problem of allocating the residues cost, but there is no general solution. The studies about the cost of the residues in comparison with generated entropy have been performed by Lozano and Valero [3] and Frangopoulos [11]. Also, the distribution of the cost of the residues proportional to the exergy has been proposed by Torres et al. [12]. A more rational criterion for allocating the residues cost was proposed by Seyyedi et al. [13].

Corresponding author: s.masoud seyedi@yahoo.com

DOI: 10.21608/ajnsa.2018.3875.1092

(C) Scientific Information, Documentation and Publishing Office (SIDPO)-EAEA 
This criterion, based on the distributed entropy in the components, is known as the distributed entropy (DE) method. A comparison between residues cost allocation proportional to the entropy generation, proportional to the exergy and proportional to the distributed entropy has been presented in Seyyedi et al. [13,14,15]. A similar method has also been proposed by Santos et al. [16] which is called H\&S model. The basis of this method is the breakup of exergy into enthalpy and negentropy. Lourenço et al. [17] applied this method to a high-temperature gas-cooled reactor (HTGR) direct combined cycle. In this study, the ECT method and the DE method are applied to a typical HTGR that is combined with a steam cycle as used in Lourenço et al. [17]. Allocation cost evaluation results by the ECT and DE methods are comparable with the results of H\&S model.

\section{Methods and Material}

\section{Exergetic cost theory (ECT) method}

In order to indicate theexergetic cost of each stream, fuel and product costs for each component, ECT method as an algebraic method applies to the energy systems. This method has been proposed by Lozano and Valero [3] who are two specialists in exergoeconomic fields. Thermoeconomic analysis distinguishes between exergy cost, formerly exergetic cost, and exergoeconomic cost. The exergy cost of a mass is the amount of exergy $(\mathrm{kW})$ required to produce this mass. The unit exergy cost of a flow represents the amount of exergy needed to obtain a unit of exergy of that flow. The exergoeconomic cost takes into account the monetary cost of the consumed fuel, namely its market price $(\$ / \mathrm{kWh})$, as well as the investment and operational cost rate of the plant $(\$ / \mathrm{h})$, and defines the amount of money required to produce a flow. Similarly, the unit exergoeconomic cost $(\$ / \mathrm{kWh})$ of a flow is the amount of monetary units needed to obtain a unit of exergy of the referred flow [12]. For more details, see References [3,14].

\section{Distributed entropy (DE) method}

The distributed entropy method has been proposed by Seyyedi et al. [13] and it is based on the distributed entropy in the components. In this method, the first step is constructing a fuel-product (FP) table (the mathematical representation of the thermoeconomic model) from each flow exergy to allocating the cost of the residues. In this study, the FP table means the distribution of fuel and product through the combined cycle. In the second step, the FP table is calculated by energy definition instead of the exergy concept where the new table is called $\mathrm{FP}^{\mathrm{H}}$ table. According to $\mathrm{T}_{0} \mathrm{~S}=\mathrm{H}-\mathrm{S}$, an $\mathrm{FP}^{\mathrm{S}}$ table is constructed by $\mathrm{FP}^{\mathrm{S}}=\mathrm{FP}^{\mathrm{H}}$-FP that represents the distribution of entropy through the combined cycle [13]. The production cost of $i$ th component is given by Torres et al. [12] and Seyyedi et al. [13]:

$C_{P, i}=C_{F, i}+C_{R, i}+Z_{i}$

where

$C_{R, i}=\sum_{r \in V_{D}} C_{r, i}$

In order to determine the values of $C_{r, i}$, it must be defined a residue cost distribution ratio $\psi_{\text {ir }}$ such as $\mathrm{C}_{\mathrm{r}, \mathrm{i}}=\psi_{i r} C_{r 0} \quad$ with $\quad \sum_{i} \psi_{i r}=1$

\section{Physical Model}

In this study, an HTGR-steam combined cycle is used to illustrate the application of the ECT method and DE method. The HTGR is a graphite moderated helium cooled reactor with ceramic coated spherical micro fuel particles. Since the working fluid (helium) of an HTGR power cycle directly cools the core of the nuclear plant, it is called a direct cycle. Fig. (1) shows a typical HTGR direct combined cycle.

The combined cycle has two closed loops being composed of a topping helium gas cycle and a bottoming steam cycle. The tapping cycle is the core of a nuclear reactor, which provides the required energy for heating the gas helium. The two cycles are connected to each other by a heat exchanger. The outlet steam from the heat exchanger is superheated in a superheater which is fed by methane. Table (1) presents the thermodynamic properties of each stream that used to construct the FP table.

\section{Results and Discussion}

The definition of fuel and product for each component of the HTGR combined cycle are presented in Table (2).

For all calculations, a code has been developed in MATLAB. According to the thermodynamic properties of the HTGR combined cycle and the definition of the fuel and product, the amounts of fuel $(\mathrm{F})$, product $(\mathrm{P})$, irreversibility $(\dot{I})$, exergetic efficiency $(\varepsilon)$, unit exergy consumption $(\mathrm{kE})$ and specific exergy destruction (kI) for each component of combined cycle are shown in Table 3. 


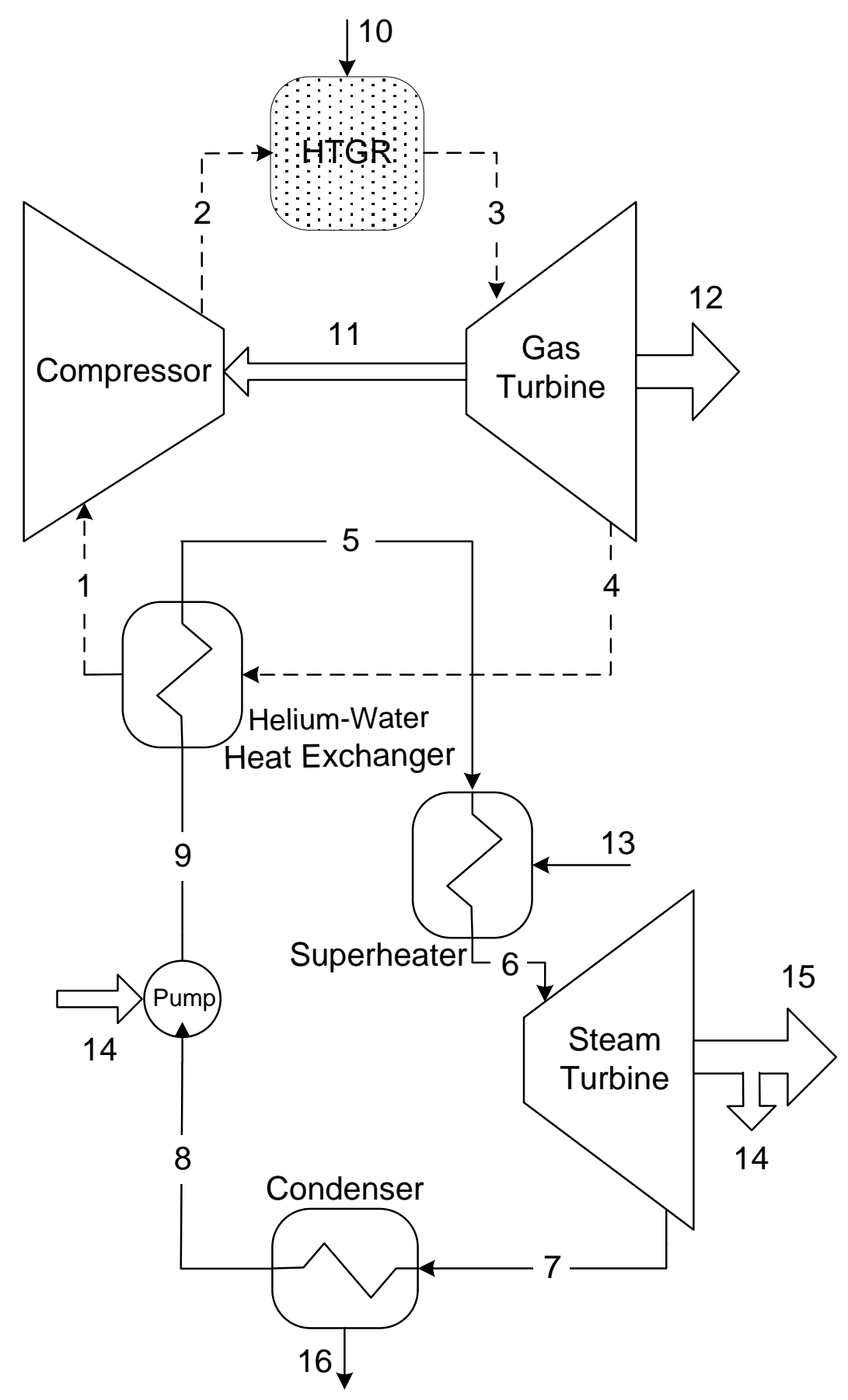

Fig. (1): Physical structure of HTGR combined cycle 
Table (1): Thermodynamic properties of the combined cycle

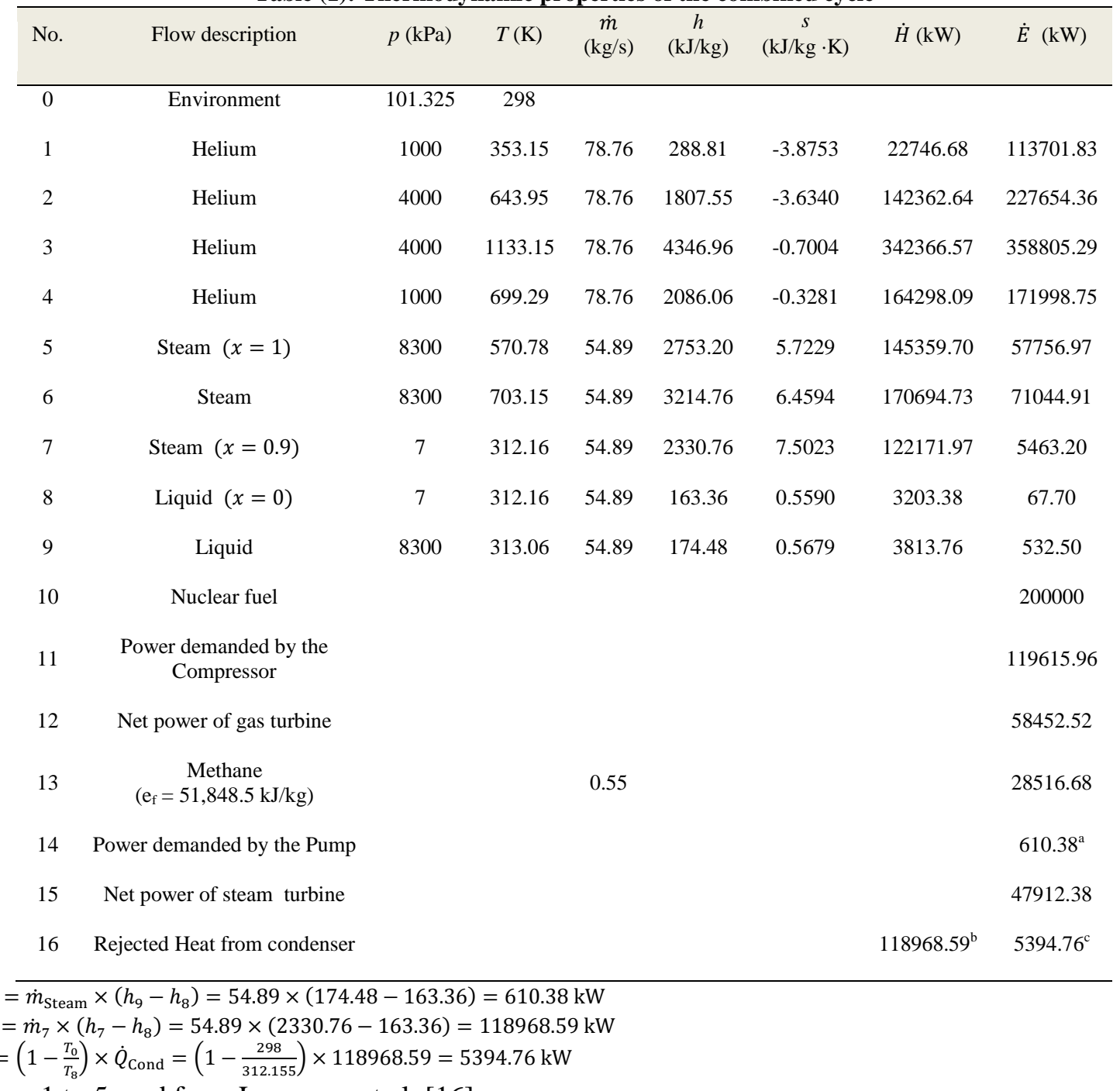

Columns 1 to 5 read from Lourenço et al. [16].

Table (2): Definition of fuel and product for each component

\begin{tabular}{ccccc}
\hline No. & Device & Fuel & Product & Type of component \\
\hline 1 & Compressor & $\dot{E}_{11}$ & $\dot{E}_{2}-\dot{E}_{1}$ & Productive \\
2 & Reactor & $\dot{E}_{10}$ & $\dot{E}_{3}-\dot{E}_{2}$ & Productive \\
3 & Gas Turbine & $\dot{E}_{3}-\dot{E}_{4}$ & $\dot{E}_{11}+\dot{E}_{12}$ & Productive \\
4 & Heat exchanger & $\dot{E}_{4}-\dot{E}_{1}$ & $\dot{E}_{5}-\dot{E}_{9}$ & Productive \\
5 & Superheater & $\dot{E}_{13}$ & $\dot{E}_{6}-\dot{E}_{5}$ & Productive \\
6 & Steam Turbine & $\dot{E}_{6}-\dot{E}_{7}$ & $\dot{E}_{14}+\dot{E}_{15}$ & Productive \\
7 & Pump & $\dot{E}_{14}$ & $\dot{E}_{9}-\dot{E}_{8}$ & Productive \\
8 & Condenser & $\dot{E}_{7}-\dot{E}_{8}$ & $\dot{E}_{16}$ & Dissipative \\
& Total & $\dot{E}_{10}+\dot{E}_{13}-\dot{E}_{16}$ & $\dot{E}_{12}+\dot{E}_{15}$ & \\
\hline
\end{tabular}


Table (3): The amounts of fuel (F), product (P), irreversibility (I), exergetic efficiency $(\varepsilon)$, unit exergy consumption (kE) and specific exergy destruction (kI) for each component of combined cycle

\begin{tabular}{cccccccc}
\hline No. & Device & $F(\mathrm{~kW})$ & $P(\mathrm{~kW})$ & $I(\mathrm{~kW})^{\mathrm{a}}$ & $\varepsilon^{\mathrm{a}}$ & $\mathrm{kE}^{\mathrm{a}}$ & $\mathrm{kI}^{\mathrm{a}}$ \\
\hline 1 & Compressor & 119615.96 & 113952.54 & 5663.43 & 0.9527 & 1.0497 & 0.0497 \\
2 & Reactor & 200000.00 & 131150.93 & 68849.07 & 0.65 .58 & 1.5250 & 0.5250 \\
3 & Gas Turbine & 186806.54 & 178068.48 & 8738.06 & 0.9532 & 1.0491 & 0.0491 \\
4 & Heat exchanger & 58296.92 & 57224.47 & 1072.45 & 0.9816 & 1.0187 & 0.0187 \\
5 & Superheater & 28516.68 & 13287.94 & 15228.74 & 0.4660 & 2.1461 & 1.1461 \\
6 & Steam Turbine & 65581.70 & 48522.76 & 17058.94 & 0.7399 & 1.3516 & 0.3516 \\
7 & Pump & 610.38 & 464.80 & 145.58 & 0.7615 & 1.3132 & 0.3132 \\
8 & Condenser $^{2}$ & 5395.50 & 5394.76 & 0.74 & 0.9999 & 1.0001 & 0.0001 \\
& Total $^{*}$ & $223121.92^{\mathrm{b}}$ & $106364.91^{\mathrm{c}}$ & $116757.01^{\mathrm{d}}$ & $0.4767^{\mathrm{e}}$ & 2.0977 & 1.0977 \\
\hline
\end{tabular}

"This row shows that the other values have been calculated, correctly.

${ }^{\mathrm{a}} I_{i}=F_{i}-P_{i}$ and $\varepsilon_{i}=\frac{P_{i}}{F_{i}}$ and $k E=\frac{1}{\varepsilon_{i}}=\frac{F_{i}}{P_{i}}$ and $k I=\frac{I_{i}}{P_{i}}$

${ }^{b} F_{\text {Total }}=\dot{E}_{10}+\dot{E}_{13}-\dot{E}_{16}=223121.92 \mathrm{~kW}$

${ }^{c} P_{\text {Total }}=\dot{E}_{12}+\dot{E}_{15}=106364.91 \mathrm{~kW}$

${ }^{d} I_{\text {Total }}=F_{\text {Total }}-P_{\text {Total }}=\dot{E}_{10}+\dot{E}_{13}-\left(\dot{E}_{12}+\dot{E}_{15}+\dot{E}_{16}\right)=\sum_{i=1}^{8} I_{i}=116757 \mathrm{~kW}$

${ }^{e} \varepsilon_{\text {Total }}=1-\frac{I_{\text {Total }}}{\dot{E}_{10}+\dot{E}_{13}-\dot{E}_{16}}=0.4767$

The details of the presented parameters in Table (3) have been defined in Torres et al. [12] and Seyyedi et al. [14]. The second law efficiency (exergetic efficiency) for the overall cycle is obtained as 0.4767 . The maximum value of irreversibility in the HTGR combined cycle is corresponding to the gas cooled nuclear reactor. By applying the ECT method to the HTGR combined cycle under study, the exergetic cost and exergoeconomic cost of each stream were calculated. These cost values are shown in Table (4).

For these calculations, the fuel cost per energy unit $\left(c_{f}\right)$ and the nuclear fuel cost per thermal exergy of the reactor $\left(c_{Q}\right)$ are considered as $4 \$ / G J$ and $0.4 \$ / G J$, respectively $[18,19]$. However, the purchase costs of components are not considered in this work. It is obvious from Table 4 that the maximum values of unit exergy cost and unit exergoeconomic cost are corresponding to stream 9 (outlet liquid from the pump) that have been estimated as $3.0106(\mathrm{~kW} / \mathrm{kW})$ and 1.3167 (cents/kWh), respectively. Besides applying the ECT method, DE method has been applied to the HTGR direct combined cycle, too. Tables (5, 6 and 7) show $\mathrm{FP}, \mathrm{FP}^{\mathrm{H}}$, and $\mathrm{FP}^{\mathrm{S}}$ tables for combined cycle, respectively.

In order to validate the obtained values in $\mathrm{FP}, \mathrm{FP}^{\mathrm{H}}$ and $\mathrm{FP}^{\mathrm{S}}$ tables illustrated in Tables (5, 6 and 7), a good comparison has been performed according to the values presented in Table (4) of Lourenço et al. [17]. Table 8 represents this comparison.

It is clear from this Table that the values of productive flow presented in Lourenço et al. [17] are in good agreement with the corresponding values of fuel or product in the Tables (5-7). For all values, the relative error is almost negligible. It should be indeed mentioned that the "H\&S model" in Lourenço et al. [17] is another face of the distributed entropy method as proposed in Seyyedi et al. [13]. Residues cost distribution ratio $\left(\psi_{i}\right)$ has been calculated by two important criteria. Firstly, using a distribution of the residues cost proportional to the exergy (option 1) [12] and secondly, using distributed entropy method (option 2) [13]. Table (9) represents a comparison between the obtained values of the residues cost distribution ratio $\left(\psi_{i}\right)$ using both criteria.

The values of the first and second columns in Table(9) shows how the values corresponding to two criteria are obtained. These two columns are used to obtain the values in columns three and four. The last column in this Table shows the relative difference between the two options. As it has been discussed in Seyyedi et al. [13], distributed entropy method is more suitable and rational than the other method. Table (10) shows exergetic costs of components using the distributed entropy method. 
Table (4): Exergetic and exergoeconomic costs for each stream

\begin{tabular}{|c|c|c|c|c|c|c|}
\hline No. & Flow description & $\dot{E}(\mathrm{~kW})$ & $B(\mathrm{~kW})$ & $b(\mathrm{~kW} / \mathrm{kW})$ & $C(\$ / \mathrm{h})$ & $c($ cent $/ \mathrm{kWh})$ \\
\hline 1 & Helium & 113701.83 & 190108.56 & 1.6720 & 273.7563 & 0.2408 \\
\hline 2 & Helium & 27654.36 & 399919.62 & 1.7567 & 575.8843 & 0.2530 \\
\hline 3 & Helium & 358805.29 & 599919.62 & 1.6720 & 863.8843 & 0.2408 \\
\hline 4 & Helium & 171998.75 & 287580.55 & 1.6720 & 414.1160 & 0.2408 \\
\hline 5 & Steam $(x=1)$ & 57756.97 & 99075.16 & 1.7154 & 147.3710 & 0.2552 \\
\hline 6 & Steam & 71044.91 & 127591.84 & 1.7959 & 558.0111 & 0.7854 \\
\hline 7 & Steam $(x=0.9)$ & 5463.20 & 9811.54 & 1.7959 & 42.9099 & 0.7854 \\
\hline 8 & Liquid $(x=0)$ & 67.70 & 121.59 & 1.7959 & 0.5317 & 0.7854 \\
\hline 9 & Liquid & 532.50 & 1603.17 & 3.0106 & 7.0113 & 1.3167 \\
\hline 10 & Nuclear fuel & 200000 & 200000 & 1 & 288.0000 & 0.1440 \\
\hline 11 & $\begin{array}{l}\text { Power demanded by the } \\
\text { Compressor }\end{array}$ & 119615.96 & 209811.07 & 1.7540 & 302.1279 & 0.2526 \\
\hline 12 & Net power of gas turbine & 58452.52 & 102528.00 & 1.7540 & 147.6403 & 0.2526 \\
\hline 13 & Methane & 28516.68 & 28516.68 & 1 & 410.6401 & 1.4400 \\
\hline 14 & Power demanded by the Pump & 610.38 & 1481.58 & 2.4273 & 6.4796 & 1.0616 \\
\hline 15 & Net power of steam turbine & 47912.38 & 16298.72 & 2.4273 & 508.6217 & 1.0616 \\
\hline 16 & Rejected Heat from condenser & 5394.76 & 9689.95 & 1.7962 & 42.3781 & 0.7855 \\
\hline
\end{tabular}

Table (5): FP Table

\begin{tabular}{|c|c|c|c|c|c|c|c|c|c|c|}
\hline & $\mathrm{F}_{0}$ & $F_{1}$ & $\mathrm{~F}_{2}$ & $\mathrm{~F}_{3}$ & $\mathrm{~F}_{4}$ & $\mathrm{~F}_{5}$ & $\mathrm{~F}_{6}$ & $\mathrm{~F}_{7}$ & $\mathrm{~F}_{8}$ & Total \\
\hline$\overline{P_{0}}$ & & & 200000 & & & 28516.68 & & & & 228516.68 \\
\hline $\mathrm{P}_{1}$ & & & & 86849.36 & 27103.18 & & & & & 113952.54 \\
\hline $\mathrm{P}_{2}$ & & & & 99957.18 & 31193.75 & & & & & 131150.93 \\
\hline $\mathrm{P}_{3}$ & 58452.52 & 119615.96 & & & & & & & & 178068.48 \\
\hline $\mathrm{P}_{4}$ & & & & & & & 52874.42 & & 4350.05 & 57224.47 \\
\hline $\mathrm{P}_{5}$ & & & & & & & 12277.82 & & 1010.11 & 13287.93 \\
\hline $\mathrm{P}_{6}$ & 47912.38 & & & & & & & 610.38 & & 48522.76 \\
\hline $\mathrm{P}_{7}$ & & & & & & & 429.46 & & 35.33 & 464.79 \\
\hline \multirow[t]{2}{*}{$\mathrm{R}_{8}$} & 5394.76 & & & & & & & & & 5394.76 \\
\hline & & 119615.96 & 200000 & 186806.54 & 58296.93 & 28516.68 & 65581.70 & 610.38 & 5395.49 & \\
\hline
\end{tabular}

Table (6): $\mathrm{FP}^{\mathrm{H}}$ Table

\begin{tabular}{|c|c|c|c|c|c|c|c|c|c|c|}
\hline & $F_{0}$ & $F_{1}$ & $\mathrm{~F}_{2}$ & $\mathrm{~F}_{3}$ & $\mathrm{~F}_{4}$ & $\mathrm{~F}_{5}$ & $\mathrm{~F}_{6}$ & $\mathrm{~F}_{7}$ & $\mathrm{~F}_{8}$ & Total \\
\hline $\mathrm{P}_{0}$ & & & 200000 & & & 28516.68 & & & & 228516.68 \\
\hline $\mathrm{P}_{1}$ & & & & 66641.14 & 52974.83 & & & & & 119615.97 \\
\hline $\mathrm{P}_{2}$ & & & & 111427.35 & 88576.58 & & & & & 200003.93 \\
\hline $\mathrm{P}_{3}$ & 58452.52 & 119615.96 & & & & & & & & 178068.48 \\
\hline $\mathrm{P}_{4}$ & & & & & & & 41006.30 & & 100539.65 & 141545.95 \\
\hline $\mathrm{P}_{5}$ & & & & & & & 7339.64 & & 17995.39 & 25335.03 \\
\hline $\mathrm{P}_{6}$ & 47912.38 & & & & & & & 610.38 & & 48522.76 \\
\hline $\mathrm{P}_{7}$ & & & & & & & 176.83 & & 433.55 & 610.38 \\
\hline \multirow[t]{2}{*}{$\mathrm{R}_{8}$} & 118968.59 & & & & & & & & & 118968.59 \\
\hline & & 119615.96 & 200000 & 178068.49 & 141551.41 & 28516.68 & 48522.77 & 610.38 & 118968.59 & \\
\hline
\end{tabular}


Table (7): FP $^{\mathrm{S}}$ Table

\begin{tabular}{|c|c|c|c|c|c|c|c|c|}
\hline & $\mathrm{F}_{0}$ & $F_{1}$ & $\mathrm{~F}_{2}$ & $F_{3}$ & $\mathrm{~F}_{4}$ & $\mathrm{~F}_{5}$ & $\mathrm{~F}_{7}$ & Total \\
\hline $\mathrm{P}_{0}$ & & & 0 & & & 0 & & 0 \\
\hline $\mathrm{P}_{1}$ & & & & -20207.95 & 25871.65 & & & 5663.7 \\
\hline $\mathrm{P}_{2}$ & & & & 11470.17 & 57382.83 & & & 68853 \\
\hline $\mathrm{P}_{3}$ & 0 & 0 & & & & & & 0 \\
\hline $\mathrm{P}_{4}$ & & & & & & -11868.12 & 96189.6 & 84321.48 \\
\hline $\mathrm{P}_{5}$ & & & & & & -4938.18 & 16985.28 & 12047.1 \\
\hline $\mathrm{P}_{6}$ & 0 & & & & & & 0 & 0 \\
\hline $\mathrm{P}_{7}$ & & & & & & -252.63 & 398.22 & 145.59 \\
\hline \multirow{2}{*}{\multicolumn{4}{|c|}{$\mathrm{R}_{8} 113573.83$}} & & & & & 113573.83 \\
\hline & & & & -8737.78 & 83254.48 & $0-17058.93$ & $\begin{array}{lll}0 & 113573.1\end{array}$ & \\
\hline
\end{tabular}

Table (8): Comparison between the values fuel and product in Table (4) of Lourenço et al. [17] and present work

\begin{tabular}{|c|c|c|c|c|c|c|c|c|c|}
\hline \multicolumn{2}{|c|}{$\begin{array}{l}\text { Table (6) in Present } \\
\text { work }\end{array}$} & \multicolumn{2}{|c|}{$\begin{array}{c}\text { Table (5) in Present } \\
\text { work }\end{array}$} & \multicolumn{2}{|c|}{ Table (4) in Ref. [17] } & \multicolumn{2}{|c|}{$\begin{array}{l}\text { Table (7) in Present } \\
\text { work }\end{array}$} & \multicolumn{2}{|c|}{ Table (4) in Ref. [17] } \\
\hline $\begin{array}{l}\text { Fuel or } \\
\text { Product }\end{array}$ & Values & $\begin{array}{l}\text { Fuel or } \\
\text { Product }\end{array}$ & Values & $\begin{array}{l}\text { Productive } \\
\text { Flow }\end{array}$ & Values & $\begin{array}{l}\text { Fuel or } \\
\text { Product }\end{array}$ & Values & $\begin{array}{l}\text { Productive } \\
\text { Flow }\end{array}$ & Values \\
\hline & & $\mathrm{F}_{1}$ & 119615 & $\mathrm{H}_{2: 1}$ & 1196 & $\mathrm{P}_{1}$ & 566 & $\mathrm{~S}_{2: 1}$ & 10 \\
\hline & & $\mathrm{F}_{2}$ & 200000 & $\mathrm{H}_{3: 2}$ & 200000 & $\mathrm{P}_{2}$ & 68853 & $S_{3: 2}$ & 68850.85 \\
\hline & & $\mathrm{P}_{3}$ & 178068.48 & $\mathrm{H}_{3: 4}$ & 178064 & $-\mathrm{F}_{3}$ & 8737.78 & $S_{3: 4}$ & 8737.13 \\
\hline $\mathrm{P}_{4}$ & 141545.95 & & & $\mathrm{H}_{4: 1}$ & 141549.04 & $\mathrm{~F}_{4}$ & 83254.48 & $\mathrm{~S}_{4: 1}$ & 83253.09 \\
\hline $\mathrm{P}_{4}$ & 141545.95 & & & $\mathrm{H}_{5: 9}$ & 141549.04 & $\mathrm{P}_{4}$ & 84321.48 & $S_{5: 9}$ & 84323.46 \\
\hline $\mathrm{P}_{5}$ & 25335.03 & & & $\mathrm{H}_{6: 5}$ & 25335.44 & $\mathrm{P}_{5}$ & 12047.1 & $S_{6: 5}$ & 12046.66 \\
\hline & & $\mathrm{P}_{6}$ & 48522.76 & $\mathrm{H}_{6: 7}$ & 48523.69 & $-\mathrm{F}_{6}$ & 17058.93 & $S_{6: 7}$ & 17059.42 \\
\hline $\mathrm{F}_{8}$ & 118968.59 & & & $\mathrm{H}_{7: 8}$ & 118971.20 & $\mathrm{R}_{8}$ & 113573.83 & $S_{7: 8}$ & 113574.96 \\
\hline & & $\mathrm{F}_{7}$ & 610.38 & $\mathrm{H}_{9: 8}$ & 610.42 & $\mathrm{P}_{7}$ & 145.59 & $S_{9: 8}$ & 145.42 \\
\hline
\end{tabular}

Table (9): Residues cost allocation based on the distributed entropy method for combined cycle

\begin{tabular}{|c|c|c|c|c|c|c|}
\hline No. & Device & Column $\mathrm{F}_{8}$ in Table & $\begin{array}{c}\text { Column } \mathrm{F}_{8} \text { in Table } \\
7\end{array}$ & $\begin{aligned} \boldsymbol{\psi}_{\boldsymbol{i}}= & \frac{\boldsymbol{E}_{\boldsymbol{i} \mathbf{8}}}{\boldsymbol{F}_{\mathbf{8}}} \\
& \text { Ref. [12] } \\
& \text { (option 1) }\end{aligned}$ & $\begin{array}{c}\boldsymbol{\psi}_{\boldsymbol{i}}=\frac{\boldsymbol{E}_{\boldsymbol{i}, \mathbf{8}}^{\boldsymbol{S}}}{\boldsymbol{F}_{\mathbf{8}}^{\boldsymbol{S}}} \\
\text { Present work and } \\
\text { Ref [13] (option 2) }\end{array}$ & $\begin{array}{l}\text { Relative difference } \\
\text { between two options } \\
(\%)\end{array}$ \\
\hline 1 & Compressor & 0.00 & 0.00 & 0.0000 & 0.0000 & 0.00 \\
\hline 2 & Reactor & 0.00 & 0.00 & 0.0000 & 0.0000 & 0.00 \\
\hline 3 & Gas Turbine & 0.00 & 0.00 & 0.0000 & 0.0000 & 0.00 \\
\hline 4 & $\begin{array}{l}\text { Heat } \\
\text { exchanger }\end{array}$ & 4350.05 & 96189.6 & 0.8062 & 0.8469 & 4.8 \\
\hline 5 & Superheater & 1010.11 & 16985.28 & 0.1872 & 0.1495 & -25.22 \\
\hline 6 & Steam Turbine & 0.00 & 0.00 & 0.0000 & 0.0000 & 0.00 \\
\hline 7 & Pump & 35.33 & 398.22 & 0.0065 & 0.0035 & -85.71 \\
\hline \multirow[t]{2}{*}{8} & Condenser & 0.00 & 0.00 & 0.0000 & 0.0000 & 0.00 \\
\hline & Total & 5395.49 & 113573.1 & & & \\
\hline
\end{tabular}


The minimum and maximum values of product unit exergetic cost $\left(c_{P}\right)$ is corresponding to the reactor and the pump that are equal to 1.5249 $(\mathrm{kW} / \mathrm{kW})$ and $3.5324(\mathrm{~kW} / \mathrm{kW})$, respectively. Residues cost $\left(C_{R}\right)$ for the heat exchanger, superheater and pump are equal to $8890.60 \mathrm{~kW}$, $1569.87 \mathrm{~kW}$, and $36.85 \mathrm{~kW}$, respectively, and for other components are equal to zero (corresponding to zero values of these components in column 4 of Table 9). Table (11) shows exergoeconomic costs of components using the distributed entropy method.

The minimum and maximum values of product unit exergoeconomic cost $\left(c_{\mathrm{P}}\right)$ is equal to 0.2196 (cents/kWh) and 3.1420 (cents/kWh), that are related to the reactor and superheater, respectively. In Table(11) the last column shows the product cost rate for each component. It is clear that the minimum and maximum values are $7.18(\$ / \mathrm{h})$ and $558.02(\$ / \mathrm{h})$ that are corresponding to the pump and steam turbine, respectively.

For better comparison, the results of product unit exergetic cost $(\mathrm{kW} / \mathrm{kW})$ and product unit exergoeconomic cost (cents/kWh) for the HTGR combined cycle, which is calculated by ECT method and DE method are presented in Fig. (2 and 3 ).

It is obvious from Fig. (2)that DE method is a more accurate method compared to the ECT method. However, product exergetic cost values predicted by the DE method are more conservative in comparison with the results of the ECT method. The maximum and the minimum product exergetic cost values in $(\mathrm{kW} / \mathrm{kW})$ HTGR combined cycle is related to the pump $(3.5 \mathrm{~kW} / \mathrm{kW})$ and the reactor $(1.4 \mathrm{~kW} / \mathrm{kW})$, respectively. In contrast, from Fig. (3) it can be seen that the combined cycle suffers from the costly superheater component. However gas-cooled reactor, as an innovated component in combined cycle under study, has an economized product unit exergoeconomic cost value.

$\mathrm{FP}^{\mathrm{S}}$ table has interesting properties which have been extensively described in References. [13,14]. Table (12) shows the calculation results of the distributed entropy method.

In Table(13), the exergy carried out by each flow is denoted as $E_{\mathrm{i}, \mathrm{j}}$ that represents the product of $i$ th component that is used as the fuel of the $j$ th component [12]. Table (12) has been constructed using Tales (5-7). For example, in this table, a focus was made on the bold-faced values for each component. These bold-faced values represent the product of $\mathrm{FP}^{\mathrm{S}}$ Table $\left(P_{i}^{S}\right)$ for each component and on the other hand, are equal to the generated entropy which has been shown in the last column of this table. It is also noted that the colored boldfaced values are $96189.6 \mathrm{~kW}, 16985.28 \mathrm{~kW}$, and $398.22 \mathrm{~kW}$. These values correspond to the heat exchanger, superheater, and pump, respectively. The sum of three values is 113573.1 which this summation that was shown in the last row of Table (9). Therefore, for calculation of residues cost distribution ratio $\left(\psi_{i}\right)$, it is enough that each of the three values is divided by the theirs summation. As mentioned before, the result was shown in Table (9). For more details, see Seyyedi et al. $[13,14]$.

Table (10): Exergetic costs of components using the distributed entropy method

\begin{tabular}{clcclc}
\hline No. & Component & $C_{P}(\mathrm{~kW} / \mathrm{kW})$ & $C_{F}(\mathrm{~kW})$ & $C_{R}(\mathrm{~kW})$ & $C_{P}(\mathrm{~kW})$ \\
\hline 1 & Compressor & 1.8412 & 209811.07 & 0 & 209811.07 \\
2 & Reactor & 1.5249 & 200000.00 & 0 & 200000.00 \\
3 & Gas Turbine & 1.7540 & 312339.07 & 0 & 312339.07 \\
4 & Heat exchanger & 1.8587 & 97471.99 & 8890.60 & 106362.59 \\
5 & Superheater & 2.2642 & 28516.67 & 1569.87 & 30086.55 \\
6 & Steam Turbine & 2.6296 & 127593.70 & 0 & 127593.70 \\
7 & Pump & 3.5324 & 1605.02 & 36.85 & 1641.87 \\
8 & Condenser & 1.9458 & 10497.32 & 0 & 10497.32
\end{tabular}


Table (11): Exergoeconomic costs of components using the distributed entropy method

\begin{tabular}{cccccc}
\hline No. & Component & $c_{P}($ cents $/ \mathrm{kWh})$ & $C_{F}(\$ / \mathrm{h})$ & $C_{R}(\$ / \mathrm{h})$ & $C_{P}(\$ / \mathrm{h})$ \\
\hline 1 & Compressor & 0.2651 & 302.13 & 0 & 302.13 \\
2 & Reactor & 0.2196 & 288.00 & 0 & 288.00 \\
3 & Gas Turbine & 0.2526 & 449.77 & 0 & 449.77 \\
4 & Heat exchanger & 0.3132 & 140.36 & 38.88 & 179.24 \\
5 & Superheater & 3.1420 & 410.64 & 6.87 & 417.51 \\
6 & Steam Turbine & 1.1500 & 558.02 & 0 & 558.02 \\
7 & Pump & 1.5449 & 7.02 & 0.16 & 7.18 \\
8 & Condenser & 0.8510 & 45.91 & 0 & 45.91 \\
\hline
\end{tabular}

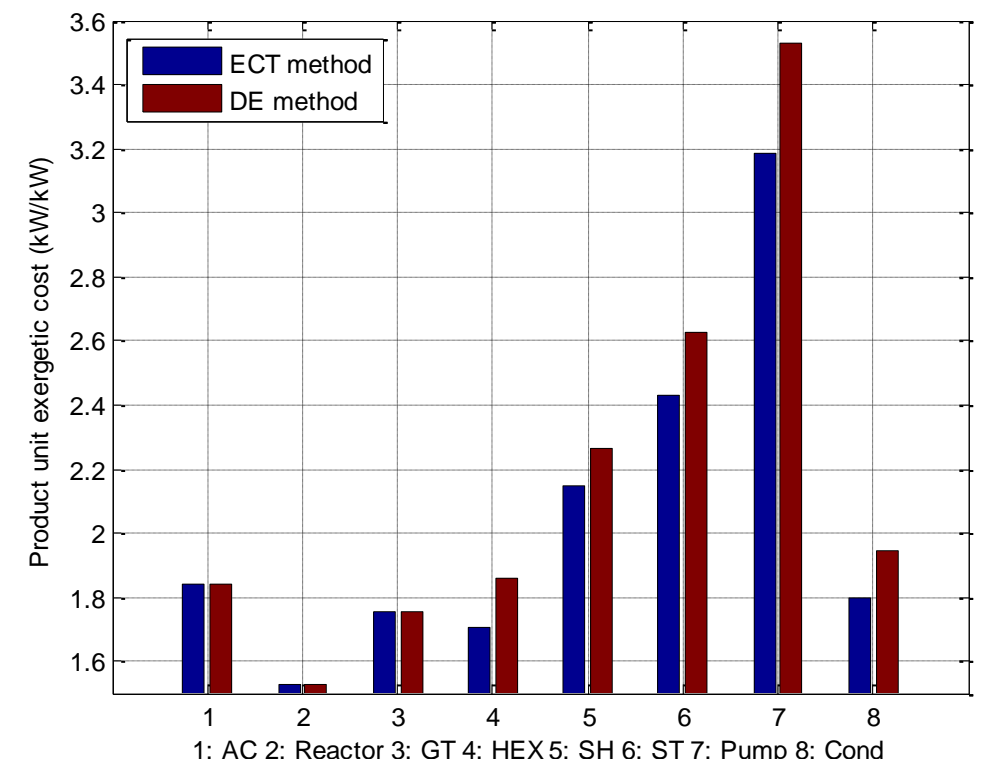

Fig. (2): Product unit exergetic cost of HTGR combined cycle

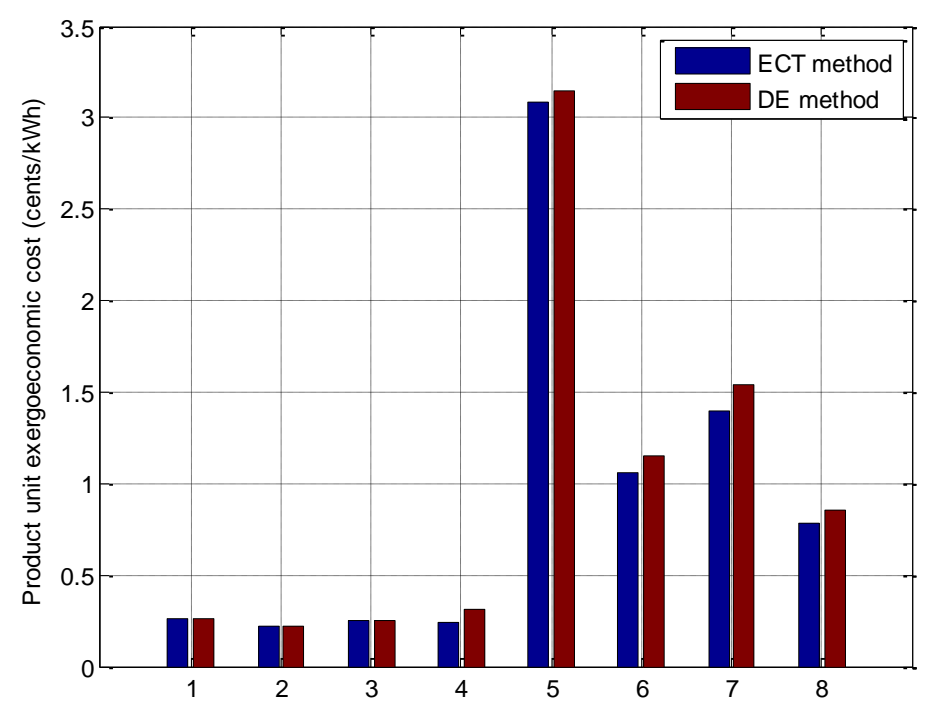

1: AC 2: Reactor 3: GT 4: HEX 5: SH 6: ST 7: Pump 8: Cond

Fig. (3): Product unit exergoeconmoic cost of HTGR combined cycle 
Table (12): Results of the distributed entropy method

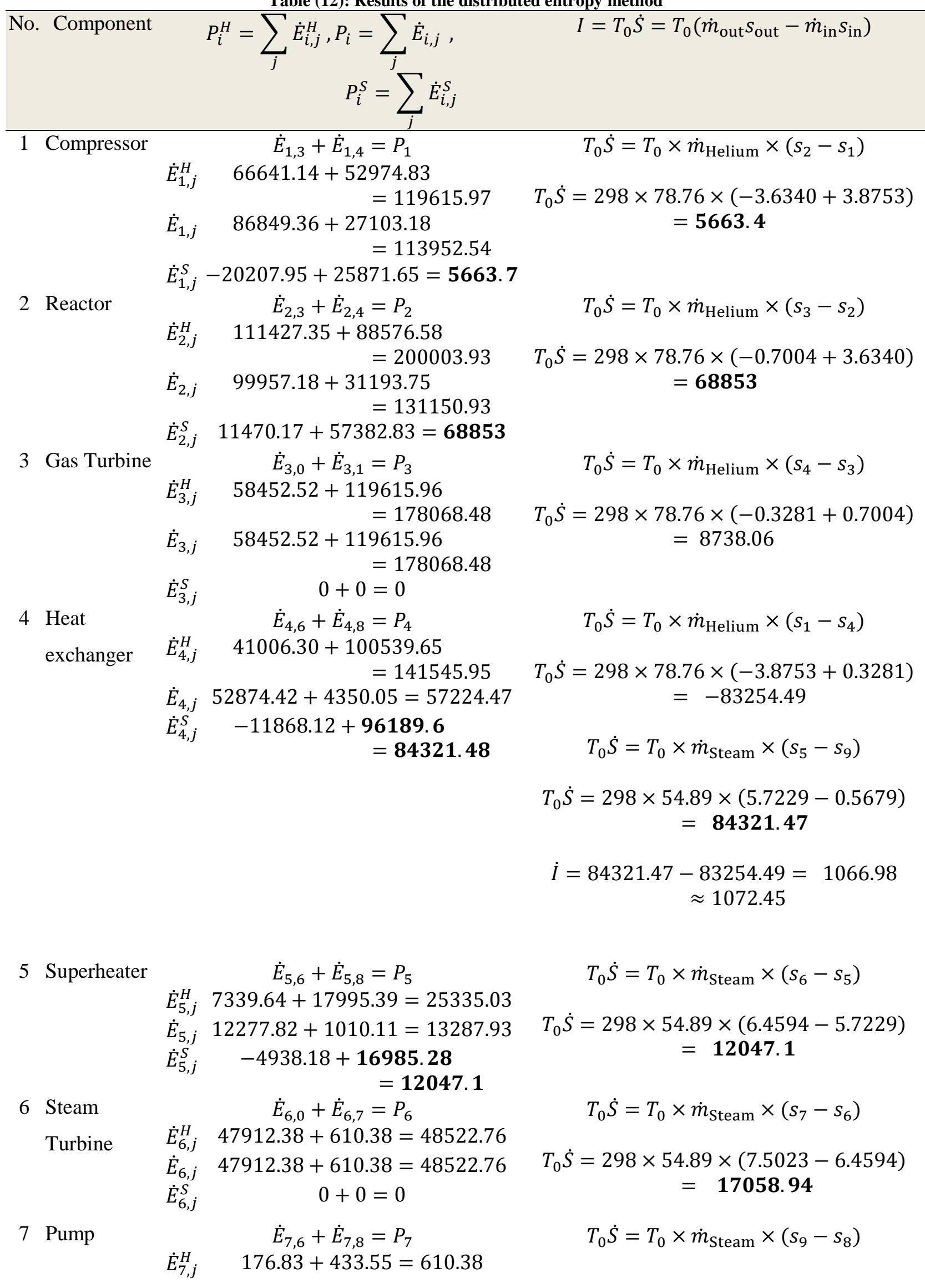




$$
\begin{array}{cc}
\dot{E}_{7, j} & 429.46+35.33=464.79 \\
\dot{E}_{7, j}^{S} & -252.63+\mathbf{3 9 8 . 2 2}=\mathbf{1 4 5 . 5 9}
\end{array}
$$

$$
\begin{gathered}
T_{0} \dot{S}=298 \times 54.89 \times(0.5679-0.5590) \\
=\mathbf{1 4 5 . 5 8}
\end{gathered}
$$

8 Condenser

\begin{tabular}{|c|c|c|c|c|c|c|c|}
\hline No. & Component & $\begin{array}{c}c_{P} \\
(\mathrm{~kW} / \mathrm{kW}) \\
\text { ECT } \\
\text { method }\end{array}$ & $\begin{array}{c}c_{P} \\
(\mathrm{~kW} / \mathrm{kW}) \\
\mathrm{DE}\end{array}$ & Error $(\%)$ & $\begin{array}{c}c_{P} \\
\text { (cents/kWh) } \\
\text { ECT method }\end{array}$ & $\begin{array}{c}c_{P}(\text { cents } / \mathrm{kWh}) \\
\text { DE method }\end{array}$ & $\begin{array}{l}\text { Error } \\
(\%)\end{array}$ \\
\hline 1 & Compressor & 1.8412 & 1.8412 & 0.0000 & 0.2651 & 0.2651 & 0.0000 \\
\hline 2 & Reactor & 1.5250 & 1.5250 & 0.0000 & 0.2196 & 0.2196 & 0 \\
\hline 3 & Gas Turbine & 1.7540 & 1.7540 & 0.0000 & 0.2526 & 0.2526 & 0.0000 \\
\hline 4 & Heat exchanger & 1.7033 & 1.8587 & 8.3588 & 0.2453 & 0.3132 & 21.6926 \\
\hline 5 & Superheater & 2.1461 & 2.2642 & 5.2179 & 3.0903 & 3.1420 & 1.6445 \\
\hline 6 & Steam Turbine & 2.4273 & 2.6296 & 7.6911 & 1.0616 & 1.1500 & 7.6911 \\
\hline 7 & Pump & 3.1876 & 3.5324 & 9.7627 & 1.3941 & 1.5449 & 9.7627 \\
\hline 8 & Condenser & 1.7962 & 1.9458 & 7.6911 & 0.7855 & 0.8510 & 7.6911 \\
\hline
\end{tabular}

$$
\begin{array}{cc}
\dot{E}_{8, j}^{H} & 118968.59=118968.59 \\
\dot{E}_{8, j} & 5394.76=5394.76 \\
\dot{E}_{8, j}^{S} & 113573.83=\mathbf{1 1 3 5 7 3 . 8 3}
\end{array}
$$

$$
\begin{gathered}
T_{0} \dot{S}=T_{0} \times \dot{m}_{\text {Steam }} \times\left(s_{7}-s_{8}\right) \\
T_{0} \dot{S}=298 \times 54.89 \times(7.5023-0.5590) \\
=\mathbf{1 1 3 5 7 3 . 0 9}
\end{gathered}
$$

Table (13): Product unit exergetic cost $(\mathrm{kW} / \mathrm{kW})$ and product unit exergoeconomic cost (cents/kWh)

\section{Conclusion}

In this work, the ECT method and the DE method were applied to a typical high-temperature gascooled reactor that directly coupled with a steam cycle through a superheater. Exergetic and exergoeconomic costs for each stream has been calculated. Also, fuel and product cost for each component has been obtained. Residues cost distribution ratio has been calculated by two important criteria and were compared with each other. The results show that criterion based on the distributed entropy is more rational than the other criterion. $\mathrm{FP}^{\mathrm{S}}$ table that has been used in distributed entropy method has interesting properties that have been extensively described. Also, the method was compared with the H\&S model. These two methods are similar. The unit product cost of gas turbine and steam turbine are calculated as 0.2526 cents $/ \mathrm{kWh}$ and 1.1500 cents/kWh, respectively. Also, the maximum product unit exergoeconomic cost value is 3.1420 cents $/ \mathrm{kWh}$ that is corresponding to superheater.

\footnotetext{
Symbols

$\boldsymbol{c}$ exergoeconomic cost (cents/kWh)

$\boldsymbol{C}$ exergoeconomic cost rate $(\$ / \mathrm{h})$

B exergetic cost $(\mathrm{kW})$
}

\section{Greek letters \\ $\varepsilon \quad$ exergetic efficiency \\ $\psi \quad$ residue cost distribution ratio}




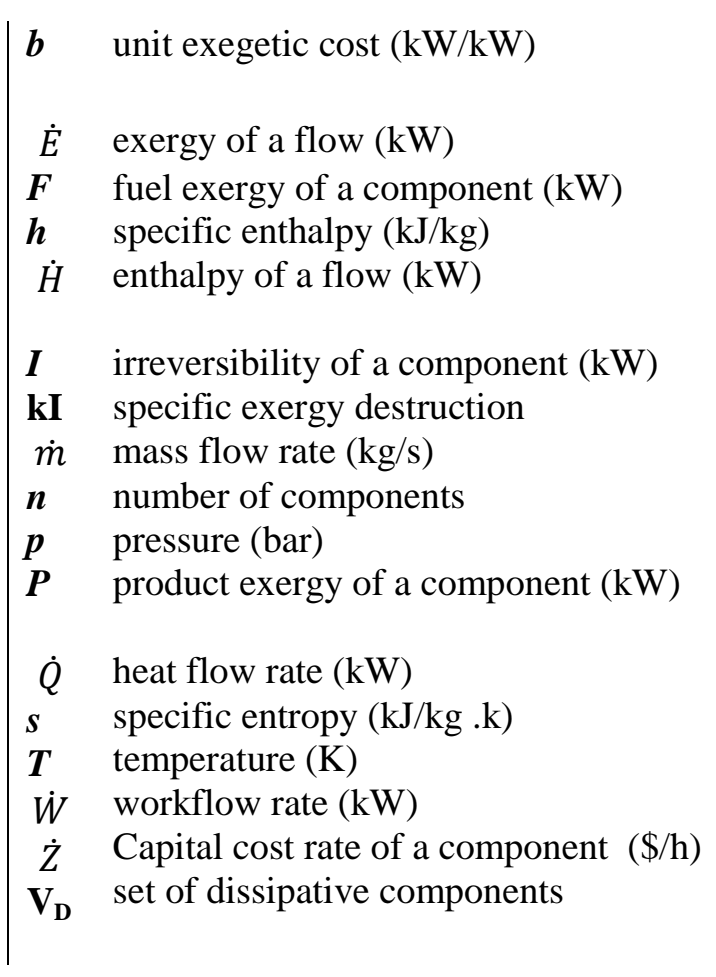

\section{References}

1- Y.M. El-Sayed, R.A. Gaggioli, A critical review of second law costing methods - I: background and algebraic procedures. ASME $\mathbf{J}$ Energy Resour Technol 111 (1989) 1-7.

2- R.A. Gaggioli, Y.M. El-Sayed, A critical review of second law costing methods - II: calculus procedures. ASME J Energy Resour Technol 111 (1989) 8-15.

3- M.A. Lozano, A.Valero, Theory of the exergetic cost. Energy Int J 18(9) (1993) 939 940.

4- A. Bejan, G. Tsatsaronis, M. Moran, Thermal design and optimization. New York, Wiley, (1996).

5- A. Lazzaretto, G. Tsatsaronis, On the calculation of efficiencies and costs in thermal systems. Proceedings of the ASME advanced energy systems division, AES-Vol. 39. New York, ASME (1999) 421-430.

6- S.M. Kim, S.D. Oh, Y.H. Kwon, H.Y. Kwak, Exergoeconomic analysis of thermal systems. Energy 23(5) (1998) 393-406.

7- Y.H. Kwon, H.Y. Kwak, S.D. Oh, Exergoeconomic analysis of gas turbine cogeneration systems. Energy Int J 1(1) (2001) $31-40$.

8- C.A Frangopoulos, Thermoeconomic functional analysis and optimization. Energy 12(7) (1987) 563-571.

9- MR. Von Spakovsky, A practical generalized analysis approach to the optimal

$\begin{array}{ll}\text { Subscripts } \\ 0 & \begin{array}{l}\text { Environment } \\ r\end{array} \\ \begin{array}{l}\text { Index for } \\ \text { components }\end{array} \\ F & \begin{array}{l}\text { related to fuel } \\ P\end{array} \\ P & \text { related to product } \\ R & \text { related to residue } \\ \text { Superscripts } \\ E & \text { related to exergy } \\ H & \text { related to energy, heat, and } \\ & \text { enthalpy } \\ S & \text { related to entropy }\end{array}$

thermoeconomic design and improvement of real-world thermal systems. Ph.D. Thesis, Georgia Institute of Technology, Georgia, (1986).

10- B. Erlach, , L.Serra, A. Valero, Structural theory as standard for thermoeconomic, Energy Convers Manage 40 (1999) $1627-$ 1649.

11- C.A. Frangopoulos, Thermoeconomic functional analysis. from Encyclopedia of Life Support System (EOLSS), developed under the auspices of the UNESCO. In: Frangopoulos CA, editor. Exergy, energy system analysis and optimization. Oxford: EOLSS Publishers, (2004)

12- C. Torres, A. Valero, V. Rangel, A. Zaleta, On the cost formation process of the residues. Energy 33 (2008) 144-152.

13- S.M. Seyyedi, H. Ajam, S. Farahat, A new criterion for the allocation of residues cost in exergoeconomic analysis of energy systems. Energy 35 (2010) 3474-3482.

14- S.M. Seyyedi, H. Ajam, S. Farahat, A new iterative approach to the optimization of thermal energy systems: application to the regenerative Brayton cycle. Proc. IMechE Part A: J. Power and Energy 224 (2010) 313-327.

15- S.M. Seyyedi, M. Hashemi-Tilehnoee, M.A. Rosen, Exergy and exergoeconomic analyses of a novel integration of a 1000 MW pressurized water reactor power plant and a gas 
turbine cycle through a superheater. Annals of Nuclear Energy, 115 (2018) 161-172.

16- J. Santos, N. Nascimento, E. Lora, A.M. Reyes, On the Negentropy Application in Thermoeconomics: A Fictitious or an Exergy Component Flow?, International Journal of Thermodynamics 12(4) (2009)163-176.

17- A. Lourenço, J. Santos, M. Donatelli, Exergy analysis and fuel exergy allocation in a HTGR direct combined cycle. Proceedings of the 20th International Conference on Nuclear Engineering collocated with the ASME Power
Conference ICONE20-POWER2012,Anaheim, California, USA, (2012).

18- A. Valero, M.A. Lozano, L. Serra, G. Tsatsaronis, J. Pisa, C.A. Frangopoulos, MR. Von Spakovsky, CGAM problem: definition and conventional solution. Energy 19(3) (1994) 279-286.

19- H. Sayyadi, T. Sabzaligoll, Exergoeconomic optimization of a $1000 \mathrm{MW}$ light water reactor power generation system. Int. J. Energy Res 33 (2009) 378-395. 